\title{
Hardly Ever
}

National Cancer Institute

\section{Source}

National Cancer Institute. Hardly Ever. NCI Thesaurus. Code C99895.

Seldom; rarely; almost never. 